\title{
METAPRAGMATIC EVALUATION OF VERBAL IRONY BY SPEAKERS OF RUSSIAN AND AMERICAN ENGLISH
}

\author{
KSENIA SHILIKHINA \\ Voronezh State University \\ shilikhina@gmail.com
}

\begin{abstract}
The paper discusses metapragmatic assessment of verbal irony by speakers of Russian and American English. The research combines ideas from metapragmatics, folk linguistics and corpus linguistics. Empirical data are drawn from the Russian National Corpus (RNC), the Corpus of Historical American English (COHA) and the Corpus of Contemporary American English (COCA). Spontaneous evaluation of linguistic behavior is an important function of both explicit and implicit metapragmatic uses of language. Distributional adjectival patterns of the Russian word ирония and English irony are treated as implicit indicators of folk metapragmatic awareness. Connotations of the adjectives reflect our everyday linguistic practices and contribute to the vagueness of the notion and the definition of irony in scholarly theorizing.
\end{abstract}

\section{Introduction}

Theories of verbal irony have a long history dating back to ancient Greeks (for a detailed historical analysis of the notion see Colebrook 2004). However, scholars interested in irony still struggle with the lack of more or less precise definition of it. As Muecke elegantly put it, "Getting to grips with irony seems to have something in common with gathering the mist; there is plenty to take hold of if only one could" (Muecke 1980:3). There are at least two reasons for such fuzziness: heavy dependence of ironic communication on immediate context and interference of lay interpretation of irony with scholarly theoretic approaches.

The idea that verbal irony is in many ways a context-dependent phenomenon is widely recognized by those involved in the research of ironic discourse (Gibbs \& Colston 2007). Modern theories of irony discuss different kinds of contextual information which contribute to processing of irony in discourse. The gamut of contextual factors that influence irony production and comprehension ranges from purely verbal signals (e.g., specific lexical choice) to extra-linguistic knowledge about the world. The major problem encountered by researchers is that external factors which influence irony processing are difficult to keep constant. Both theoretical and empirical methods are used in linguistics, psychology and cognitive science to keep track of these factors with various degrees of success (see, for example, Wilson \& Sperber 1992, Attardo 2001, Giora \& Fein 2007). 
Another source of fuzziness mentioned earlier is the interference of scholarly notion of irony with naïve understanding of what kind of linguistic behavior can be called irony. Folk awareness of ironic use of language is indicated by various metapragmatic markers. The first section of the paper discusses metalinguistic aspects of communication in professional and lay talk about language.

\section{Metalinguistic and metapragmatic discourse}

The tradition to pay attention to metalinguistic aspect of communication goes back to Roman Jakobson, who wrote:

Like Moliere's Jourdain, who used prose without knowing that it was prose, we practice metalanguage without realizing the metalingual character of our statements. Far from being confined to the sphere of science, metalingual operations prove to be an integral part of our verbal activities. (Jakobson 1985: 117).

Metalinguistic and metapragmatic activities constitute an important part of our everyday discourse. The distinction between the two kinds of language awareness comes from the traditional opposition "language-as-a-system vs. language-in-use". Metalinguistic comments reflect what people think about language as a semiotic system with its own norms and rules.

Speakers can use metalinguistic markers to negotiate the choice of words both in written and spoken discourse. The following examples taken from Russian National Corpus and the Corpus of Contemporary American English illustrate how speakers arrive at the optimal mode of expressing ideas:

Франиузы беспечнее, их дома лукаво выглядывают на улииу симпатичными фасадами, но садики кажутся слегка небрежными и, если можно так выразиться, растрёпанными (RNC).

"The French are more light-hearted, facades of their houses slyly look at the street, but the gardens seem slightly negligent and, if one may say so, disheveled."

(2) Анализируя расстановку кандидатских сил, видишь, что по крайней мере в двух округах предсточт жестокая борьба, а лучше сказать, бой: хуками слева и справа, нокаутами и досрочными окончаниями поединка $(R N C)$.

"Analyzing disposition of the candidates, you can notice that at least in two counties there will be a fierce fight, or, better put it, a battle with left and right hooks, knockouts and early finishing off."

(3) For Democrats, it was the opposite: liberals and moderates proved better informed, with 62 percent of both groups passing, but just 36 percent of conservative Democrats did so. In other words, conservative Democrats pulled down the numbers for both their ideology and their party, while the centers of both parties were the least engaged (COCA). 
And I think partly, if I may say so, that's the effect of television, where everybody seems to be under pressure to beat, you know, somebody else on what's going on the news (COCA).

In discourse studies metalinguistic expressions are sometimes referred to as discourse markers (Schiffrin 1988). Their primary function is to focus on language as a code (in Jakobsonian sense) and regulate language use.

While metalinguistic remarks illustrate the speaker's attitude towards the form and semantics of the utterance, metapragmatic comments refer to the quality of social organization of communication; in essence, they illustrate what people think about the use of language, or rather, contextually situated linguistic interaction. Verschueren calls metapragmatic awareness "a crucial force behind the meaning-generating capacity of language in use" (Verschueren 2000: 439). Silverstein (1993) discusses metapragmatic function of language from a semiotic perspective and claims that the nature of relations between linguistic signs and the context in which they are used is indexical. Metapragmatic function ensures interactional coherence of discourse. In other words, the major function of metapragmatic reflection is managing the process of communication and marking one's identity and social position.

Because both metalinguistic and metapragmatic reflections constitute an essential part of our everyday discourse, it is absolutely reasonable to treat metalanguage as a dimension of language rather than a separable object:

While a discussion of this dimension would have to refer to all metalinguistic phenomena covered by the object notion of 'metalanguage', it moves beyond such phenomena into the realm of basic properties of any stretch of discourse, thus significantly expanding the relevance of the notion (Verschueren 2000: 440).

What kinds of linguistic signs can be treated as metapragmatic markers? The answer to this question depends on the approach to metalanguage either as a separate object or a dimension of language (Verschueren 2000). Taking the latter perspective Verschueren makes an important distinction between explicit and implicit indicators of metapragmatic awareness. Explicit indicators include speech act verbs, performatives, discourse markers, sentence adverbs etc. The group of implicit means comprises most shifters, aspect, mood, modality, prosodic cues, proper names and other linguistic means which situate utterances in a particular context. Verschueren remarks that the list is open-ended (Verschueren 1999, Verschueren 2000).

The terminology and taxonomies of metapragmatic indicators discussed so far illustrate the tradition of metalinguistic thinking done by professional linguists. However, one doesn't have to be an expert in linguistics to think about the language and express thoughts about linguistic behavior just like there is no need to become a doctor to think and talk about health. As Dixon (1992: 83) notes, "All human beings have an appreciation of their native language - they will comment on whether something is grammatical or felicitous or appropriate to say in a certain situation".

Metalinguistic activity of lay speakers receives attention from linguists as "Every naïve language user not only speaks or writes or understands language, he/she is constantly controlling every step of this activity, and eventually arrives at conceptualizations and generalizations of various degrees of profoundness" (Kashkin 
2007: 179). Linguistic analysis of folk metalinguistic activity usually focuses on speech verbs and names of linguistic actions. The major task of such research is to place human language in a general world view (Arutyunova 2000).

However, not all professional language scholars are happy about naïve linguistic thoughts. When discussed by linguists, folk ideas about language face every possible criticism:

From a scientific perspective, folk beliefs about language are, at best, innocent misunderstandings of language (perhaps only minor impediments to introductory linguistic instruction) or, at worst, the bases of prejudice, leading to the continuation, reformulation, rationalization, justification, and even development of a variety of social injustices (Niedzielski \& Preston 2003:1).

For the present work we adopt a perspective that folk metalinguistic and metapragmatic awareness is a rich source of information about language in use. In particular, we focus on the ways speakers of Russian and English evaluate ironic mode of discourse.

\section{Adjectives as a source of implicit metapragmatic information}

When a speaker uses the noun ирония/irony to characterize someone's speech, he/she makes an explicit metapragmatic comment. However, the name itself does not tell us much about pragmatic functions and effects of ironic use of language. For better understanding of the role irony plays in a discursive community we need to look for other indicators of metapragmatic evaluation. The nearest contexts of the words ирония/irony function as sources of implicit metapragmatic information. The general picture of how the two lexemes are used in Russian and American English can be obtained by addressing language corpora. Corpus data shows that the nouns are often accompanied by adjectives which, along with their denotative meaning, bring connotations.

Most research on adjectives as a word class concentrates on their syntactic properties (predicating/nonpredicating syntactic behavior) or their semantic taxonomies (Raskin \& Nirenburg 1995) or syntactic behavior (Tucker 1998). Adjectives traditionally are treated as words that express additional information: "The conventional wisdom on adjectives is that they modify nouns and that they usually denote some properties of things denoted by nouns" (Raskin \& Nirenburg 1995 : 4). In the present research we focus on connotations of adjectives - the peripheral part of their semantics which, as we suggest, contributes to metapragmatic use of language.

Adjectives have not been treated as implicit data of folk beliefs about irony mostly because manual collection of such data was time-consuming. Today, however, language corpora with all their advantages of automatic data search allow us to get a full picture.

Semantic analysis of adjectives and their connotations in particular reveals what speakers of Russian and American English think of irony. Furthermore, recurring patterns of collocations can be interpreted in pragmatic terms: they tell us what pragmatic effect can be achieved in ironic discourse. Connotations function as attitudinal markers and specify the role of verbal irony in a particular context. 
The next section of the paper presents a brief discussion of corpus methods and their applicability to the research of naïve metapragmatic evaluation of verbal irony.

\section{Corpus data}

The generally acknowledged advantages of using corpora in linguistic research can be summarized as follows: corpora as a handy tool for linguistic studies made it possible to move from researcher's intuition to a systematic description of empirical data (McEnery et al. 2006). Today we can observe patterns and tendencies of language-in-use. Large sets of data can be generated easily, and finally, the linguists can check our intuition about language with statistical methods.

Most corpus-based research is focused around grammatical aspect of language use, but corpora allow us to observe not only grammatical, but also lexical patterns. "You shall know a word by the company it keeps!" - this often-cited quotation from J. R. Firth (1957) brings us to the idea that in natural language word combinations are not totally random, and in the process of written and oral communication speakers have to observe both syntactic and lexical constraints. The systematicity of lexical collocations - a phenomenon which traditionally seemed chaotic and unsystematic - can now be studied from both qualitative and quantitative perspectives (Glynn 2010).

Heated debates go around methods of analysis of collocations (see, for example, Newman 2010) because the notion of collocation itself remains controversial in linguistics (Bartsch 2004, Evert 2009). Just like the concept of irony, collocation has to be redefined every time because of multiple interpretations. In this research following the so-called neo-Firthian approach (Bartsch 2004, Evert 2009) collocation is understood as any recurring combination of two or more words.

The goal of lexical patterns research is usually to identify recurrent combinations and those collocates which are the most characteristic for the keyword. Because this work focuses on verbal irony, Russian noun ирония and English irony will serve as keywords. Their combinatorial properties will be the main focus of the next section.

\section{Metapragmatic evaluation of irony}

Most people are fairly sure that they know what they mean when they call somebody's speech ironic. However, to define criteria which the speakers apply to this characteristic is not as easy as one may think. When asked directly, people say something like "Irony is making fun of something or someone" or even "Irony is an arrogant way of speaking". Subjective interpretations, though explicit, are only a part of the whole picture. As noted above, a lot of metapragmatic activity is implicit and often goes unnoticed. Wittgenstein wrote in his "Philosophical Investigations": "The aspects of things that are most important for us are hidden because of their simplicity and familiarity" (Wittgenstein 2009: 56). The hypothesis is the following: when the speaker or the writer calls someone else's speech 'irony'/ 'ирония' or adds the adverb ironically to a speech verb (e.g. say/remark/answer ironically), it is a clear example of explicit metapragmatic reflection. But when the adjective is added to the noun ирония or irony, the speaker/writer implicitly evaluates this linguistic behavior. Collocations 'adjective + irony' / 
'прилагательное + ирония' are combinations of explicit and implicit use of metalanguage.

The research uses data from Russian National Corpus (www.ruscorpora.ru), Corpus of Historical American English (http://corpus.byu.edu/coha/) and Corpus of Contemporary American English (http://corpus.byu.edu/coca/). From the chronological perspective they provide comparable data: the texts reflect the development of Russian and American English in the past two centuries. The majority of tokens extracted from the corpora are people's comments about their own speech and linguistic behavior of other interlocutors. The collocational patterns of the two words - ирония and irony were extracted with respect to syntactic consistency of word pairs. The adjectives were taken in their attributive position only (e.g. bitter irony).

The Russian National Corpus offered a total of 745 contexts with the bigram ' $a d j+$ ирония' while COCA and COHA gave 1493 examples. Russian ирония has 172 adjective collocates and English irony - 487 adjectives.

The next step was data-cleaning: both in Russian and English the words ирония/irony refer to various kinds of irony (e.g. ирония судьбы or situational irony). Because this research was initially restricted to verbal irony only, the tokens were "sifted" manually to leave only those which describe irony as a verbal action: they contain either direct speech of characters or speech verbs or both, like in examples (5), (6), (7) and (8).

(5) II think Ryan's being paranoid again. He's been cut out of this end of the treaty works, and he's trying to remind us how important he is. Marcus agrees with my assessment, but forwarded the report out of a fit of objectivity," Liz concluded with heavy irony.

(6) II don't see your name on any of next Tuesday's ballots... does that mean you've given up on politics?" I said, with what I thought was obvious irony.

(7) Томас всегда рассказывает о своём заболевании абсолютно без горечи, с лёгкой иронией и в то же самое время с невероятным чувством грусти и нежности по отношению к своей маме, пожилой скромной немке, у которой в глазах можно прочитать всю её жизнь: что она чувствовала, ожидая ребёнка, какое смятение ошутила, поняв, что её вина в том, что сын родился таким.

"Thomas always talks about his illness without bitterness, with light irony and at the same time with great sadness and tenderness towards his mother, an elderly German lady whose eyes tell everything about her life: what she felt like expecting a baby and how desperate she became when she knew that her son was ill-born".

(8) Когда на доме, где в последние годы (с 1964 по 1969) жил академик В. В. Виноградов (это в Калашном переулке), была установлена мемориальная доска, его "добропорядочная жена" заметила с горькой иронией: "Не похож".

"When a memorial plate was placed on the house (the one in Kalashnyj Lane) where academician V.V. Vinogradov spent his last years (from 1964 till 1969), his 'respectable wife' noted with bitter irony: "He doesn't look himself". 
The final concordance contains 450 valid tokens and 141 adjectives for Russian and 297 contexts and 151 adjectives for English. The adjectives that describe other kinds of irony (e.g. situational irony or irony of fate/history etc.) were excluded. For instance, all tokens from COCA and COHA where irony was characterized as great (which initially was the most frequent collocate with 94 tokens) refer exclusively to situational irony:

(9) The great irony of Mrs. Clinton's race -- I mean, she's not doing very well against Guiliani right now. What she needs is Bill Bradley as the Democratic presidential nominee. The great irony of this race is how could Mrs. Clinton win? You need a huge Democratic turnout, a big Democratic victory in New York. How's that going to happen? If Bradley's the nominee. He's a New York Knick, as we just saw (COCA).

\subsection{Metapragmatic evaluation of verbal irony by speakers of Russian}

The distributional profile of the Russian noun ирония shows that горькая (bitter), легкая (light), злая (evil), тонкая (subtle), язвительная (acid), нескрываемая (unconcealed), грустная (sad), добродушная (aтiable), скрытая (hidden), явная (apparent) are the most frequent qualities that speakers of Russian ascribe to irony. Горькая ирония (bitter irony) is the apparent "leader" with 64 tokens. Interestingly, the adjectives share some semantic properties: they ascribe ironic speech the qualities traditionally attributed to human propensities (злая/evil, грустная/sad, добродуиная/amiable) and physical properties of objects (their size, weight, taste). In other words, an abstract notion of irony is metaphorically categorized as a human or a physical object. For instance, adjectives едкая (acid), язвительная (acid), conceptualize irony as a chemical substance.

Table 1 presents patterns of surface cooccurrence of the Russian ирония with adjectives the frequency of occurrence of which is higher than 3 .

\begin{tabular}{|l|l|l|c|}
\hline № & Adjective & English Translation & No. of Tokens \\
\hline 1 & горькая ирония & bitter irony & 64 \\
\hline 2 & легкая ирония & light irony & 44 \\
\hline 3 & злая ирония & evil irony & 30 \\
\hline 4 & тонкая ирония & subtle irony & 19 \\
\hline 5 & едкая ирония & acid irony & 13 \\
\hline 6 & нескрываемая ирония & unconcealed irony & 12 \\
\hline 7 & грустная ирония & sad irony & 11 \\
\hline 8 & добродушная ирония & amiable irony & 10 \\
\hline 9 & скрытая ирония & hidden irony & 10 \\
\hline 10 & явная ирония & apparent irony & 9 \\
\hline 11 & мрачная ирония & gloomy irony & 6 \\
\hline
\end{tabular}




\begin{tabular}{|c|l|l|c|}
\hline № & Adјесtive & English Translation & No. of Tokens \\
\hline 12 & глубокая ирония & deep irony & 6 \\
\hline 13 & благодушная ирония & kindhearted irony & 5 \\
\hline 14 & ласковая ирония & tender irony & 5 \\
\hline 15 & мягкая ирония & soft irony & 5 \\
\hline 16 & небрежная ирония & careless irony & 5 \\
\hline 17 & язвительная ирония & acid irony & 5 \\
\hline 18 & романтическая ирония & romantic irony & 4 \\
\hline 19 & убийственная ирония & killing irony & 4 \\
\hline 20 & вызывающая ирония & provocative irony & 3 \\
\hline 21 & высокомерная ирония & haughty irony & 3 \\
\hline 22 & грубая ирония & rude irony & 3 \\
\hline 23 & добрая ирония & kind irony & 3 \\
\hline 24 & едва заметная ирония & subtle irony & 3 \\
\hline 25 & малейшая ирония & slightest irony & 3 \\
\hline 26 & неуловимая ирония & elusive irony & 3 \\
\hline 27 & обычная ирония & usual irony & 3 \\
\hline 28 & сдержанная ирония & reserved irony & 3 \\
\hline 29 & снисходительная ирония & patronizing irony & 3 \\
\hline 30 & спасительная ирония & saving irony & 3 \\
\hline 31 & тотальная ирония & total irony & 3 \\
\hline 32 & угрюмая ирония & gloomy irony & \\
\hline
\end{tabular}

Table 1. Distributional profile of the Russian word ирония

The data shows that there is significant disagreement among speakers of Russian about the properties and effects of ironic communication in various contexts (e.g. irony can be apparent or hidden, evil or kind). Fifteen adjectives out of 32 presented in Table 1 bear negative connotations, six evaluate irony as a positive linguistic behavior and 11 are neutral. There is a clear tendency for the word ирония to co-occur predominantly with adjectives with negative connotations. How can the tendency be interpreted? Here we can apply the concept of semantic prosody coined by John Sinclair (semantic profile in Michael Stubbs's terminology) - a tendency of a word to co-occur with either positive or negative words (Sinclair 1991, Stubbs 1995). Because negative connotations of adjectives dominate over positive and neutral ones, the semantic prosody of the Russian word ирония also tends to be negative. This means that speakers of Russian tend to perceive verbal irony mostly as a communicative disturbance.

At this point we need to address the problem of low-frequency collocations. For Russian, only 32 adjectives fit the frequency threshold. More than a hundred adjectives 
occur only once or twice. Does their low frequency mean that they are included in our set of data by chance only and we should simply dispose of them? Or is there another way of using them?

Any natural language gives us a variety of options how to express our thoughts. Every time we speak we make a rational choice from a range of words, syntactic constructions, etc. A closer look at the list of adjectives and their semantic analysis shows that some of them function as near-synonyms or belong to the same type of metaphoric description of irony. This leads us to the next step in our analysis - the adjectives are grouped into chains of contextual synonyms regardless of their surface frequency. Eleven chains were named by the most frequent adjectives and the total number of tokens in each chain was counted. Diagram 1 presents the number of tokens for each synonymic chain.

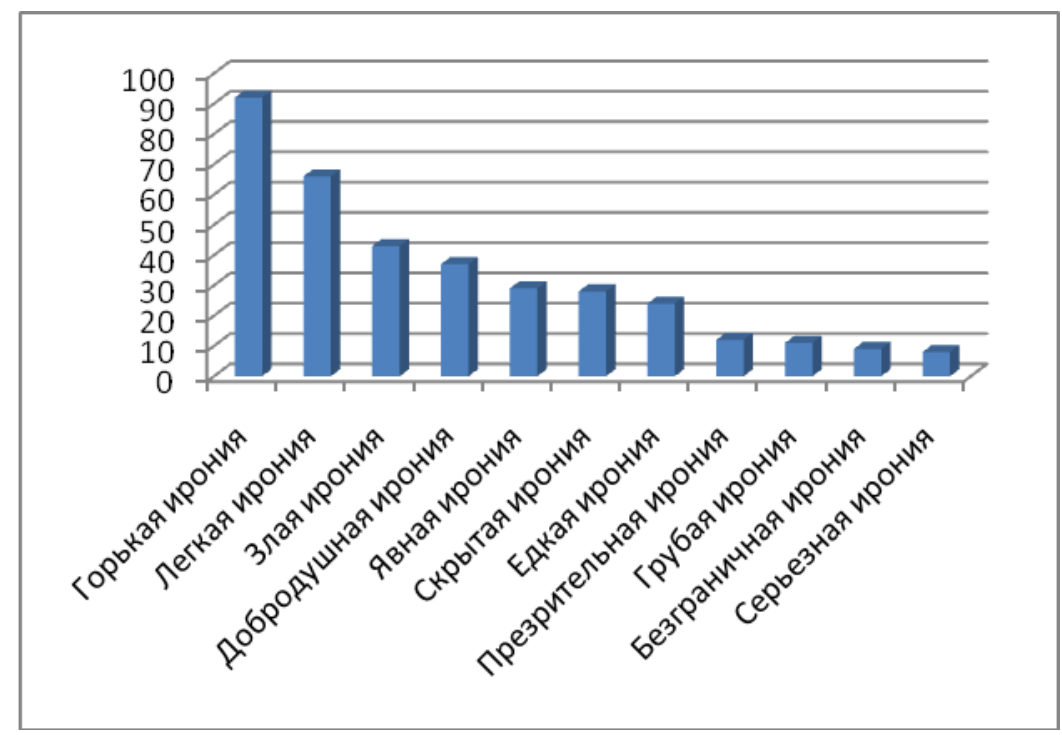

Diagram 1. Chains of near-synonyms for Russian

The longest Russian chain is горькая (bitter) - мрачная (dark) - угрюмая (gloomy) хмурая (gloomy) - унылая (sad) - грустная (sad) - щемящая (painful, melancholy) безнадежная (hopeless) - печальная (sad) - обидчивая (touchy).

The following examples $(10-15)$ illustrate semantic closeness of the adjectives in the chain of synonyms.

(10) Об этих двух своих сыновьях Наталья Михайловна говорила с горькой иронией.

"Natalia Mikhailovna spoke about these two sons of hers with bitter irony"

(11) - Как у тещи, - с мрачной иронией сказал кто-то...

"Just like at the mother-in-law's, - said someone with dark irony" 
(12) - А я полагал, по тому самому ты и порекомендуешь меня на должность! - с резкой и угрюмой иронией проговорил молодой человек.

"And I thought because of that you would recommend me for the position! - said the young man with sharp and gloomy irony".

(13) Так вы закончили, господин Никитин, тем, что исчерпываете проблему отсутствием доказательств, и я почувствовал в ответе какую-то хмурую иронию, не так ли?

(14) - Где уж мне! - с унылою иронией сказал Петр.

"As if I can! - said Peter with sad irony"

(15) - Спасибо! - с обидчивой иронией сказала она.

"Thank you! - she said with touchy irony.

Again, the majority of synonymic chains contain adjectives with negative connotations. This confirms to our conclusion that Russian noun ирония tends to have a negative semantic prosody and ironic communication is evaluated negatively at the metapragmatic level of discourse by the speakers of Russian.

\subsection{Metapragmatic evaluation of verbal irony by speakers of Russian}

The semantic profile of the word irony in American English is not so clear. Two collocates - heavy and bitter - are the most frequent adjectives with 25 and 23 tokens respectively. The adjectives with frequency higher than 3 are listed in Table 2.

\begin{tabular}{|l|l|c|}
\hline № & Adjective & No. of tokens \\
\hline 1 & Heavy irony & 25 \\
\hline 2 & Bitter irony & 23 \\
\hline 3 & Fine irony & 10 \\
\hline 4 & Quiet irony & 9 \\
\hline 5 & Grim irony & 7 \\
\hline 6 & Unconscious irony & 7 \\
\hline 7 & Mock irony & 6 \\
\hline 8 & Gentle irony & 5 \\
\hline 9 & Playful irony & 5 \\
\hline 10 & Unintentional irony & 5 \\
\hline 11 & Gloomy irony & 4 \\
\hline 12 & Beautiful irony & 3 \\
\hline 13 & Cold irony & 3 \\
\hline 14 & Dry irony & 3 \\
\hline 15 & Elaborate irony & 3 \\
\hline 16 & Friendly irony & 3 \\
\hline 17 & Good-natured irony & 3 \\
\hline 18 & Light irony & 3 \\
\hline 19 & Malicious irony & 3 \\
\hline
\end{tabular}




\begin{tabular}{|c|l|c|}
\hline № & Adjective & No. of tokens \\
\hline 20 & Mild irony & 3 \\
\hline 22 & Savage irony & 3 \\
\hline 23 & Weary irony & 3 \\
\hline
\end{tabular}

Table 2. Distributional profile of the word irony in American English

Though two large corpora of American English were used, the number of recurrent combinations is lower than in Russian. In American English verbal irony does not seem to be a popular object of metapragmatic comments. Nota bene, another proof is functioning of the delocutive verbs for ironic speech in Russian and American English. The verb to ironize is used in academic discourse only (COCA suggests only four instances of its use while COHA offers none!). In contrast, Russian verb иронизировать (to speak ironically) is used in both spoken and written discourse, and the Russian National Corpus offers 534 instances of its metapragmatic uses.

It is easy to notice that negative adjectives (e.g. heavy, bitter, grim) are among the most frequent, but there are also positive collocates (e.g. fine, quiet, gentle, playful, beautiful, mild). Like in Russian, there are contrastive evaluations of irony, but we cannot say that irony is viewed predominantly as something that creates problems in communication.

The adjectives were also grouped into 12 chains of near-synonyms. It comes to no surprise that the two chains - heavy and bitter - have the largest number of tokens.

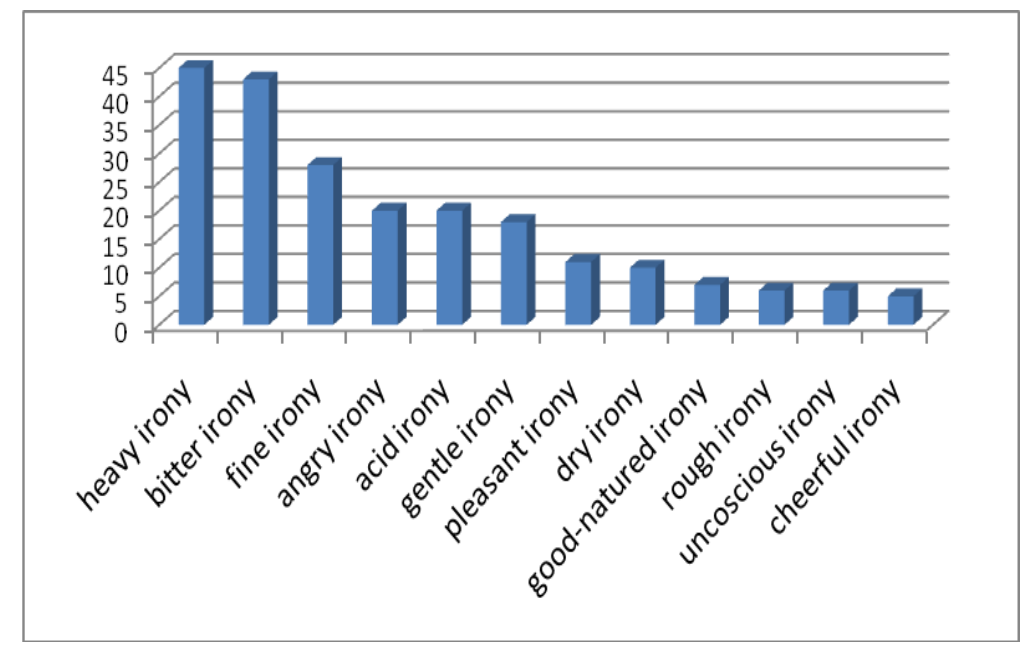

Diagram 2. Chains of near-synonyms for American English

Interestingly, almost all synonymic chains have clear connotations, either negative (heavy, bitter, angry, acid, dry, rough irony) or positive (fine, gentle, pleasant, goodnatured, cheerful). Again, we cannot talk of any tendencies, predominantly positive or negative semantic prosody of the word irony and the associations it has in American culture. 


\section{Conclusion}

What generalizations can be made from our data? Firstly, speakers of Russian and American English are well aware of irony as a specific discursive practice, that is, a particular linguistic behavior with its own rules of production and interpretation in various contexts. If we compare irony to other ways of non-literal use of language, we will see that metaphor, let alone metonymy, does not get as much attention and appreciation from language speakers. There are no bitter or good-natured metaphors or heavy or sad metonymies.

Folk interpretations of irony present a functional perspective: adjectives tell us what irony does in discourse. A wide variety of social functions (Hutcheon 1992) and pragmatic effects is yet another explanation of a large number of adjectives that characterize verbal irony. Good-natured, kind or light kinds of irony do not disrupt interpersonal relationships, while evil, acid or haughty irony is a signal of aggressive verbal behavior.

The number of adjectives in both languages shows that verbal irony is not just using words to mean the opposite, or echoic mention, or pretence. It is a complex verbal action which can produce a wide range of pragmatic effects, most of which are negative.

Another conclusion is that there are various ways of metapragmatic use of language: it can be implicit, just as the language it describes. This goes along with the cybernetic law of requisite variety (Ashby 1957), according to which a complex system needs a system of management (metalanguage in the case of natural languages) of at least of the same degree of complexity.

Most adjectives describing properties of ironic utterances are not neutral; they have either negative or positive connotation (e.g., bitter irony, fine irony) and as such display people's attitude towards ironic discourse. Speakers of Russian tend to evaluate irony mostly negatively, as a communicative disturbance.

Finally, our naïve understanding of irony leads to the vagueness of the notion and the definition of irony in scholarly theorizing. Fuzziness of the folk idea of ironic communication penetrates linguistic theories of verbal irony and results in lack of a rigorous definition.

\section{References}

Arutyunova, N.D. 2000. Naivnye razmyshleniya o naivnoy kartine yazyka [Naïve considerations on naïve view of language]. In N.D. Arutyunova (ed.), Yazyk o yazyke [Language About Language]. Moscow: Yazyki russkoy kultury.

Ashby, W. Ross. 1957. An Introduction to Cybernetics. London: Chapman \& Hall LTD.

Attardo, S. 2001. "Irony as Relevant Inappropriateness". Journal of Pragmatics, 32, 793-826.

Baker, P. 2010. "Corpus Methods in Linguistics". In L. Litosseliti (ed.), Research Methods in Linguistics (93-116). London \& New York: Continuum.

Bartsch, Sabine. 2004. Structural and Functional Properties of Collocations in English. Tübingen: Gunter Narr Verlag.

Colebrook, C. 2004. Irony. New York: Routledge. 
Dixon, R.M.W. 1992. Naïve Linguistic Explanation. Language in Society 21, 83-91.

Evert, S. (2009). Corpora and Collocations. In A. Lüdeling \& M. Kytö (eds.), Corpus Linguistics: An International Handbook (1212-1248). Berlin: Walter de Gruyter.

Firth, J. R. 1957. A synopsis of linguistic theory 1930-55. In Studies in linguistic analysis (1-32). Oxford: The Philological Society.

Gibbs, Raymond W. \& Herbart L. Colston (eds.) 2007. Irony in Language and Thought. A Cognitive Science Reader. New York \& London: Lawrence Erlbaum Associates.

Giora, R. \& O. Fein. 2007. "Irony: Context and Salience". In R.W. Gibbs \& H.L. Colston (eds.), Irony in Language and Thought. A Cognitive Science Reader (201216). New York \& London: Lawrence Erlbaum Associates.

Glynn, D. \& K. Fischer (eds.). 2010. Quantitative Methods in Cognitive Semantics: Corpus-Driven Approaches. Berlin \& New York: Walter de Gruyter.

Hutcheon L. 1992. The Complex Functions of Irony. Revista Canadiense de Estudios Hispánicos Vol. 16, No. 2, 219-234.

Jakobson, R. 1985. Metalanguage as a linguistic Problem. In Selected Writings VII. The Hague: Mouton (113-121).

Kashkin, Viatcheslav B. 2007. Metalinguistic Activity and Everyday Philosophy. In Language in Action. Vygotsky and Leontievian Legacy Today (179-202). Cambridge: Cambridge Scholar Publishing.

McEnery, T., R. Xiao \& Y. Tono. 2006. Corpus-Based Language Studies. London \& New York: Routledge.

Muecke, D. 1980. The Compass of Irony. London \& New York: Routledge.

Niedzielski, Nancy A. \& Dennis Richard Preston. 2003. Folk Linguistics. Berlin \& New York: Walter de Gruyter.

Newman, J. "Balancing Acts: Empirical Pursuits in Cognitive Linguistics". In G. Dylan \& K. Fischer (eds.), Quantitative Methods in Cognitive Semantics: Corpus-Driven Approaches (79-100). Berlin \& New York: Walter de Gruyter.

Raskin, V. \& S. Nirenburg. 1995. Lexical Semantics of Adjectives. A Microtheory of Adjectival Meaning. In Recent Papers from the Mikrokosmos and Corelli Projects. Vol 2. New Mexico: New Mexico State University.

Schiffrin, D. 1988. Discourse Markers. Cambridge: Cambridge University Press.

Silverstein, M. 1993. Metapragmatic Discourse and Metapragmatic Function. In J.A. Lucy (ed.), Reflexive Language: Reported Speech and Metapragmatics (33-60). Cambridge: Cambridge University Press.

Sinclair, J.M. 1991. Corpus, Concordance, Collocation. Oxford: Oxford University Press.

Stubbs, M. 1995 Collocations and Semantic Profiles: On the Cause of the Trouble with Quantitative Studies. Functions of Language 2(1), 23-55.

Tucker, G. 1998. The Lexicogrammar of Adjectives: A Systemic Functional Approach to Lexis. London \& New York: Continuum International Publishing Group.

Verschueren, Jef. 1999. Understanding Pragmatics. London: Edward Arnold.

Verschueren, Jef. 2000. Notes on the Role of Metapragmatic Awareness in Language Use. Pragmatics 10:4, 439-456.

Wilson, D. \& D. Sperber. 1992. On Verbal Irony. Lingua, 87, 53-76.

Wittgenstein, Ludvig. 2009. Philosophical Investigations. Oxford: Wiley-Blackwell. 


\begin{abstract}
About the Author
Ksenia Shilikhina is an Associate Professor of Linguistics at Voronezh State University, Russia. Her research interests include semantics and pragmatics with a special focus on verbal irony. Another area of interest is corpus linguistics. She teaches courses in Linguistic Typology, Semiotics, Applied and Computational Linguistics and Formal Models in Linguistics.
\end{abstract}

